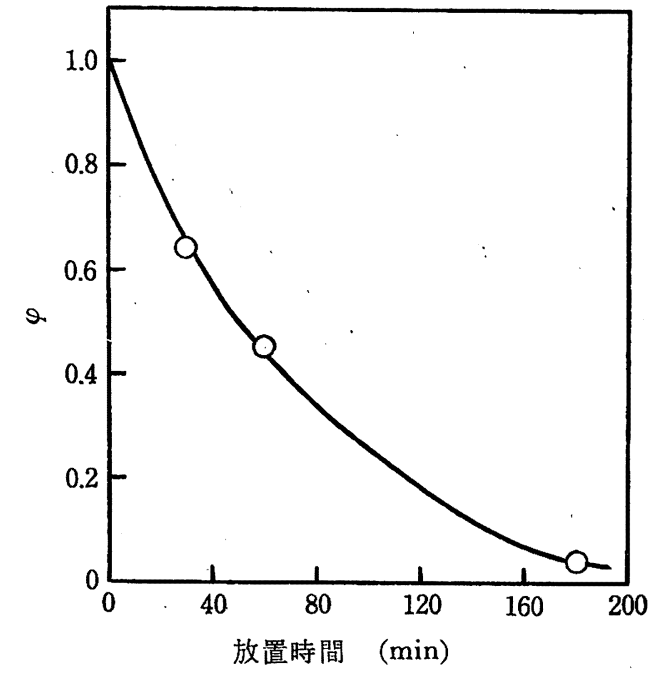

図 6 酸化性物質の残存分密と放置時間

存分率 $\varphi^{* 8}$ との関係を図 6 に示した。図から明らかなように，時

*8 残存分率 $\varphi$ はつぎのように定義する. $\varphi=[\mathrm{Ox}]_{t} /[\mathrm{Ox}]_{i}$

$[\mathrm{Ox}]_{i}$ および $[\mathrm{Ox}]_{t}$ はそれぞれ酸化性物質の初期およ び時間 $t$ における収量.
間の経過とともに酸化性物質が減少する。また $\gamma$ 線照射を行なっ た試料についても同様な傾向を示した。これは加熱時間の経過と ともに，酸化性物質より安定なヨウ素酸イオンになると考えられ る。このことは Boydら9の臭素酸りチウム塭について, 加熱温 度と酸化性物質との関係から，温度が高いほど酸化性物質の減少 がすみやかであるので，この分解機構は高エネルギー粒子による “熱的スパイク”仮説では説明できないとしている。ヨウ素酸り チウム塩の ${ }^{6} \mathrm{Li}(n, \alpha){ }^{3} \mathrm{H}$ 反応による放射線分解は，系素酸りチ ウム塩の場合と同様な傾向を示していることにより，この仮説で は説明できないと一応推定される。このことに関しては，さらに 十分な研究が必要であると考えられる。

本研究にあたり, 御助言ならびに御支援を賜わった東北大学理 学部塩川孝信教授, ならびに静岡大学放射化学研究施設神原富尚 教授に深謝する。また， 北大学工学部 ${ }^{60} \mathrm{Co}$ 照射室, 日本原子力研究所大学開放研究室の みなさま，および中性子照射は京都大学原子炉実験所のみなさま に心から謝意を表する。

(1967 年 10 月, 第 11 回放射化学討論会 (一部)；1968 年 4 月， 第 5 回理工学における同位元素研究発表会(一部)講演)

\title{
ハロイサイトから合成した $\mathbf{A}$ 型ゼオライトの吸着特性 $*_{1}, *_{2}$
}

(昭和 43 年 7 月 17 日受理)

\author{
高 橋 浩・西 村 陽 一*3
}

\begin{abstract}
結晶度の低いハロイサイトから合成したA型ぜオライトの吸着特性を容量法およびスプリングバランス法によって調べた。 八ロイサイトから合成した $\mathrm{A}$ 型ゼオライト(ゼオライト $\mathrm{A}^{\prime}$ ) の吸着特性はモレキュラーシーブ $\mathrm{A}(\mathrm{M} . \mathrm{S} . \mathrm{A})$ の吸着特性と異なる。 すなわち，ナトリウム型において，モレキュラーシーブ $\mathrm{A}$ は $n$-パラフィン $\left(>\mathrm{C}_{3}\right)$ を吸着しないのに対して，ナトリウムーゼオライ ト $\mathrm{A}^{\prime}$ はかなりの量の $n$-パラフィンを吸着する。またカルシウム型において，モレキュラーシーブ $\mathrm{A}$ はインパラフィンを吸着しな いことが知られているが，カルシウムーゼオライト $\mathrm{A}^{\prime}$ はイソブタンを吸着する。これらの笑験結果はゼオライト $\mathrm{A}^{\prime}$ の平均細孔が 対応するモレキュラーシーブ Aの細孔よ大きいととを示している。化学分析その他の結果から，原料八ロイサイト中に不純物と

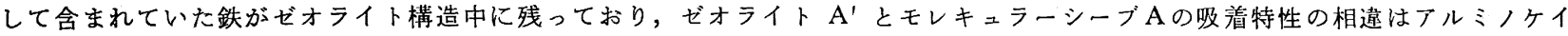
酸塩骨格中の鉄の置換によるものと考えられる。
\end{abstract}

\section{1 緒 言}

$\mathrm{A}$ 型ゼオライトは $\mathrm{Me}_{2} / n \mathrm{O} \cdot \mathrm{Al}_{2} \mathrm{O}_{3} \cdot 2 \mathrm{SiO}_{2} \cdot m \mathrm{H}_{2} \mathrm{O}$ (Me は アル カリあるいはアルカリ土類金属, $n$ はその電荷数)であらわされる 化学組成のゼオライトであって, 天然には存在せず, Breck ら1) によってケイ酸ナトリウム，アルミン酸ナトリウムなどを出発物 質としてはじめて合成され，その吸着特性はモレキュラーシーブ として著名である2)。A型ゼオライトの構造は Breck, Shoemaker

*1 この報交を“ゼオライトの研究(第 3 報)”とする.

*2 前報(第 2 報), 高橋 浩, 西村陽一, 日化, 89, 373 (1968).

*3 Hiroshi Takahashi, Yōichi Nishimura 東京大学生産 技術研究所第 4 部, 東京都港区六本木

1) D. W. Breck, W. G. Eversole, R. M. Milton, T. L. Thomas, J. Am. Chem. Soc., 78, 5963(1956).

2) G. K. Hersh, "Moleculer Sieves", Reinhold Pub. Corp., New York(1961).
らによって報告されているが，ソーダライト胞の角落し八面体 (truncated octahedron)が単位立方体の八隅を占めて結合し, 酸 絜の四，六，および八員環からなる均一な細孔を有している334。 また $\mathrm{A}$ 型ゼオライトの陽イオンは他の 1 価あるいは 2 価の陽イオ ンと容易に交換し，酸素八員瑷からなる細孔の径は陽イオンの種 によって異なる。すなわち，ナトリウム型の場合には細孔径が約 $4 \AA$ であるのに対して, カルシウム型では約 $5 \AA$, カリウム型で は約 $3 \AA$ になる。

著者らはさきに結晶度の巽なる数種のカオリン鉱物とアロフェ ン0)水酸化ナトリウム処理による栦造変化に関する研究を行な い，結晶度のいちじるしく低いハロイサイトおよびアロフェン0 場合には適当な条件のもとで純度の高いA型ゼオライトが生成す

3) T. B. Reed, D. W. Breck, J. Am. Chem. Soc., 78, 5972 (1956).

4) L. Broussard, D. P. Shoemaker, ibid., 82, 1041(1960). 
ることを見いだした5)。また八ロイサイトを出発物質とするホー ジャサイト型ゼオライ、トの生成について報告した6)。

A 型ゼオライトの吸着特性についてはすでに詳しく報告されて いるが，著者らはハロイサイトを出発物質として生成したA型ゼ オライトとモレキュラーシーブA (M.S. A)の吸着特性について 比較検討を行ない，両者の吸着特性に相違を見いだしたので報告 する。

\section{2 実験}

\section{1 出発試料および処理条件}

出発試料として用いた八ロイサイトは前報に述べた試料と同じ く, 結晶度のいちじるしく低い種の伊那カオリン(長野県, 駒ケ 根産)である6。

水酸化ナトリウム処理は試料粘土 $50 \mathrm{~g}$ に水酸化ナトリウム $15 \mathrm{~g}$, 水 $50 \mathrm{ml}$ を加えてよく混合し, $70^{\circ} \mathrm{C} て ゙ 24$ 時間加熱処理 を行なった。生成物はホタル石を内部標準として，X線回折法に よる定量分析を行ない，A型ゼオライト含有量が 100\%であるこ とを確認した。

生成したA型ゼオライトはナトリウム型であり，これをカリウ ム型またはカルシウム型に交換するためにつぎの处理を行なっ た。試料 $3 \mathrm{~g}$ をそれぞれ $4.7 \%$ の塩化カリウム溶液をたは $3.5 \%$ の塩化カルシウム溶液 $100 \mathrm{~m} l$ 中に加えて, 常温で 48 時間静置 してイオン交換を行なって，K-拈よび Ca-A型とし，ナトリウ ム型とともに測定試料とした。またカルシウムイオンの交換率の， 影響を調べるため, 浱度の異なる塩化カルシウム溶液によって， カルシウムイオンの交換率の異なるA型ゼオライトを作製しあわ せて測定試料とした。また比較試料としてシリカゲル(和光純薬 製)，モレキュラーシーブ $3 \mathrm{~A} ， 4 \mathrm{~A}$ おび $5 \mathrm{~A}$ (いずれも粉末， Linde 社製)を用いた。

\section{2 吸着実験}

水蒸気, $n$-ブタン, イソブタンおよび $n$-ヘプタンの吸着等温 線は石英スプリングを用いる重量法によって求めた。測定温度は $30^{\circ} \mathrm{C}$ である。また液体窒素の沸点に㧍ける窒素ガスの吸着量を 容量法によって求め, 窒素吸着量から BET法によって陚料の表 面積を求めだ。試料はシリカゲルをのぞいてすべて $300^{\circ} \mathrm{C}$, $10^{-4} \mathrm{mmHg}$ で 3 時間脱気し，一定圧のもとで 24 時間放置して 吸着量を求めた。シリカゲルのみ加熱温度を $180^{\circ} \mathrm{C}$ 。とした。水 蒸気圧の調節は各種無機塩類の 飽和水溶液および 硫酸一水の系它 用いて行なった。っーブタンはモレキュラーシーブ4 Aのトラップ を通して不純物として含まれるエタン，エチレンなどをのぞき， イソブタンはモレキュラーシーブ5 Aのトラップによって n-ブ タンなどの不純物究のでいた。また $n$ ーヘプタンは五酸化リンを 加光て蒸留し，さらにモレキュラーシーブ4 Aのトラップを通し て用いた。

5）高橋 浩, 西村陽一，日化，88，528(1967).

6）前報(第 2 報)，高橋 浩，西村陽一，日化，89，373 (1968).

*4 ゼオライトはモレキュラーシーブ $3 \mathrm{~A}, 4 \mathrm{~A}$ をのぞいて, 普通は窒素が細孔内部に入るため，単分子層を形成する と考元る BET 法によって求められる比表面積とはとの 意味が異なり, 相当表面積 (equivalent monolayer surface area)と呼ぶべきであるが，本報告ではこれを表面 積とした。

\section{3 結果と考察}

\section{1 化学分析結果}

表 1 亿用いた $\mathrm{A}$ 型ゼオライトの化学分析結果を示す。モレキュ ラーシーブ $4 \mathrm{~A}$ および $5 \mathrm{~A}$ は鉄, マグネシウムなどをほとんど含 まないのに対して，ハロイサイトを出発物質として生成した $\mathrm{A}$ 型 ゼオライト(モレキュラーシーブ $\mathrm{A} に$ 対して $\mathrm{A}^{\prime}$ と略す)の場合に はカリウム, ナトリウム, カルシウムのいずれの型の試料におい ても鉄とマグネシウムが含まれている。これらは原料ハロイサイ ト中に含まれていたもので, ゼオライト化したのちにる除去され ずに残っている。またとれらの鉄とマグネシウムは塩化カリウ ム，塩化カルシウム溶液などによるイオン交換を行なっても除く ととはできない。

表 1 試料として用いたA 型ぜオライトの化学分析結果 (\%) $\left(110^{\circ} \mathrm{C}, 2\right.$ 時間乾燥試料)

\begin{tabular}{lrrrrr}
\multicolumn{1}{r}{ 試料 } & \multicolumn{1}{c}{ M.S 4A, } & M.S. 5A & \multicolumn{1}{c}{ K-A } & Na-A' & \multicolumn{1}{c}{$\mathrm{Ca}-\mathrm{A}^{\prime}$} \\
$\mathrm{SiO}_{2}$ & 35.33 & 33.99 & 34.17 & 35.83 & 33.93 \\
$\mathrm{Al}_{2} \mathrm{O}_{3}$ & 32.84 & 32.15 & 31.48 & 31.85 & 29.78 \\
$\mathrm{Fe}_{2} \mathrm{O}_{3}$ & 0.01 & 0.01 & 2.07 & 2.10 & 2.16 \\
$\mathrm{CaO}$ & 0.00 & 13.80 & 0.00 & 0.00 & 8.72 \\
$\mathrm{MgO}$ & 0.08 & 0.00 & 0.27 & 0.32 & 0.87 \\
$\mathrm{Na}{ }_{2} \mathrm{O}$ & 19.50 & 5.70 & 3.35 & 16.80 & 6.19 \\
$\mathrm{~K}_{2} \mathrm{O}$ & 0.00 & 0.00 & 13.26 & 0.00 & 0.00 \\
強熱減量 & 12.34 & 15.34 & 15.20 & 13.30 & 18.40
\end{tabular}

これらの試料のイオン交換率はモレキュラーシーブ $5 \mathrm{~A}$ の場 合, $72.8 \mathrm{~mol} \%, \mathrm{Ca}-\mathrm{A}^{\prime}$ の場合には $61 \mathrm{~mol} \%, \mathrm{~K}-\mathrm{A}^{\prime}$ の場には $72 \mathrm{~mol} \%$ でる。カルシウム型の場 合，その交換率が $40 \mathrm{~mol} \%$ 以上であれば $5 \mathrm{~A}$ とての吸着特性を示すことから， Ca-A' は モレギュラーシーブ $5 \mathrm{~A}$ 相当と見ることができる。

\section{2 水蒸気吸着}

化学处理を行なわない場合のハロイサイトの水蒸気吸着能はあ まり高くないが，水酸化ナトリウム処理を行なうと水蒸気吸着能 は非常に高くなる。これは前報に述べたように水酸化ナトリウム 処理によって，ハロイサイトのるとの構造がこわれ，無定形状態 になり，さらにA型ゼオライト，ヒドロキシソーダライトなどの 新しい結晶相が生成するためである。図 1 亿八ロイサイト，八ロ． イサイトを出発物質として生成した $\mathrm{A}^{\prime}$ ，モレキュラーシーブ $\mathrm{A}$ およびシリカゲルなどの水蒸気吸着等温線を示す。末処理のハ口 イサイトは比蒸気圧の低いところでは吸着量が少なく，比蒸気圧 が 1 に近づくと吸着量が増加するいわゆる逆 $\mathrm{S}$ 字型吸着曲線を描 く。またシリカゲルも比蒸気圧の低いととろでは吸着量が 少な く,比蒸気压の増加にとるなって吸着量がほぼ直線的に増加して, 比蒸気圧の高いととろでは非常に大きな吸着能を有するととを示 している。これに対してA型ゼオライトの場合には，Langmuir 型の極端な吸着等温線を描き，極性分子を強く吸着する恃性を示 し, 比蒸気圧の非常に低いところですでに吸着量柱多く、比蒸気 圧が高くなってるほとんど吸着量は増加しない。ナトリウム型と カルシウム型を比較するとカルシウム型の方がわずかに吸着量は 多く，またナトリウム型が低い比蒸気圧のところで飽和するのに 対して，カルシウム型では比蒸気圧の増加にともなってわずが 吸着量は増加する。ほた八ロイサイトから生成した $\mathrm{A}$ 型ゼオライ ト $\left(\mathrm{A}^{\prime}\right)$ と対応するモレキュラーシーブAを此較すると両者の間に 


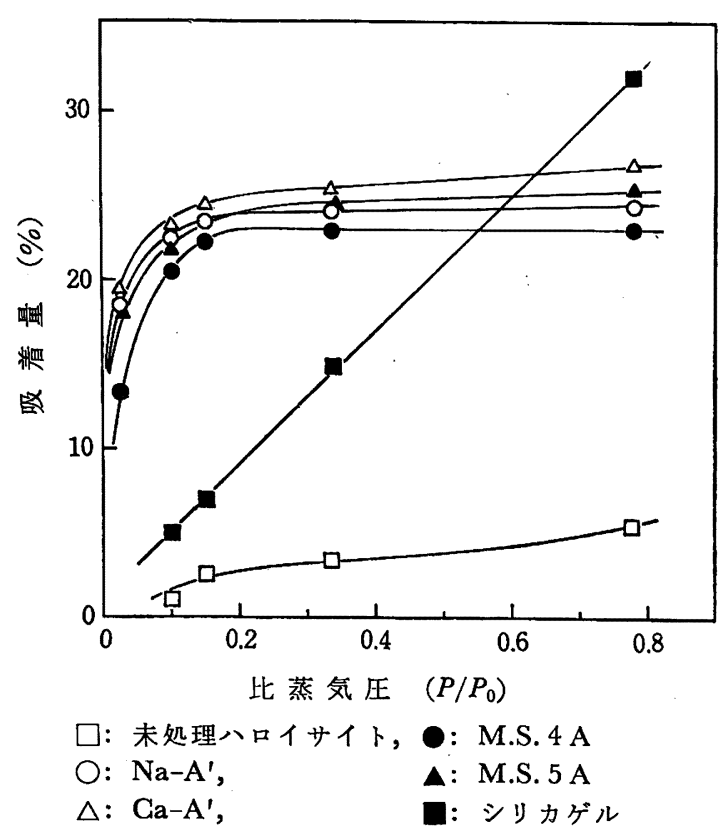

図 1 水蒸気吸着等温線 $\left(30^{\circ} \mathrm{C}\right)$

わずかな相違がある。 $\mathrm{A}^{\prime}$ の場合には $\mathrm{Na}-\mathrm{A}^{\prime} ， \mathrm{Ca}-\mathrm{A}^{\prime}$ のいずれも それぞれ対応するモレキュラーシーブ $4 \mathrm{~A} ， 5 \mathrm{~A}$ よりも高い吸着 能を有していて, $P / P_{0}=0.15$ のところでは $\mathrm{Na}-\mathrm{A}^{\prime}$ の吸着量はモ レキュラーシーブ $5 \mathrm{~A}$ の吸着量とほぼ同じ值になる。

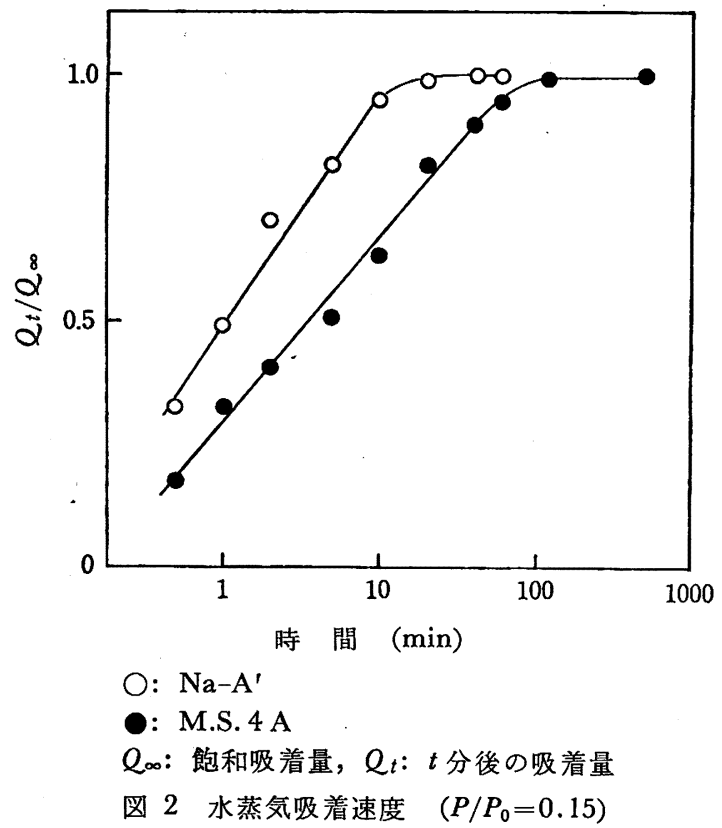

両者の相違は水蒸気吸着速度においても認められる。図 2 に $P / P_{0}=0.15$ における $\mathrm{Na}-\mathrm{A}^{\prime}$ と $4 \mathrm{~A}$ の水蒸気吸着速度を示す。 $\mathrm{Na}-\mathrm{A}^{\prime}$ は吸着開始後約 1 分で飽和吸着量の $1 / 2$ に達するが， 4 Aでは約 5 分必要である。また $\mathrm{Na}-\mathrm{A}^{\prime}$ は約 10 分で飽和吸着量 の 95\%，40 分で $99 \%$ 対するのに対して，4Aでは飽和吸着に 達するのに約 2 時間必要であって, $\mathrm{Na}-\mathrm{A}^{\prime}$ にくらべてかなり遅 い。Na-A' の吸着速度は $4 \mathrm{~A}$ よりもむしろカルシウム型の $5 \mathrm{~A}$ と同じ傾向を示す。

\section{3 窒絜吸着および表面積}

水蒸気吸着において認められたハロイサイトから生成した $\mathrm{A}$ 型 ゼオライト $\left(\mathrm{A}^{\prime}\right)$ と対応するモレキュラーシーブ $\mathrm{A}$ の吸着特性の 相違は低温における窒素吸着の場合さらに明らかである。眓 3 に

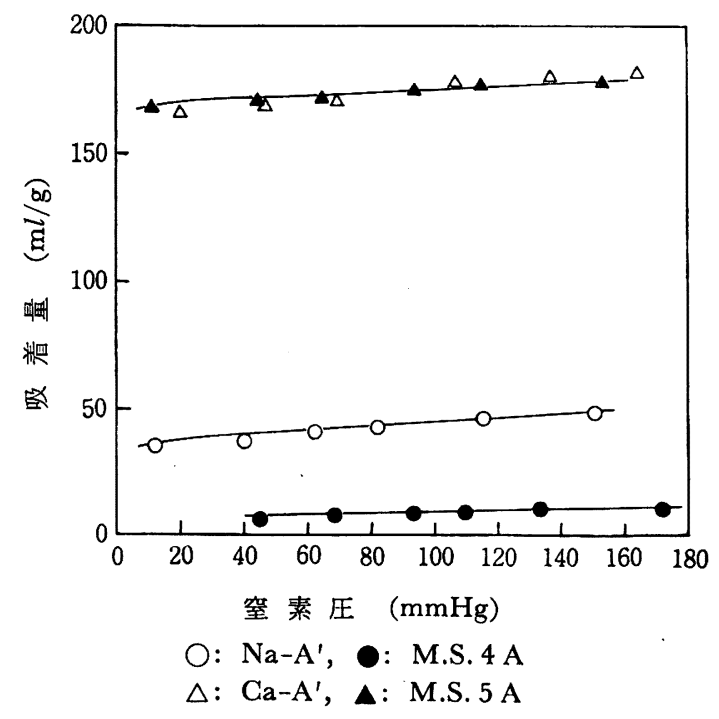

図 3 窒素吸着等温線

窒素の沸点における窒素ガスの吸着等温線を示す。モレキュラー シーブ $4 \mathrm{~A}$ ほ極低温において窒素をほとんど吸着しないことが知 られている7。細孔径に近い分子径のものは極低温において細孔 内への拡散抵抗が大きく, 吸着されるに十分な活性化ェネルギー を有さないため吸着速度がきわめて遅くなり，吸着平衡に達しな いためである。このような極低温における吸着の異常性はカルシ ウムーモルデナイトに拈けるアルゴンの财着においても認められ ている8)。本実験においても，罒に示されているように4 Aでは 数 $\mathrm{m} l(\mathrm{STP}) / \mathrm{g}$ 程度の窒素を吸着するにすぎない。これに対して 4 A 対応する $\mathrm{Na}-\mathrm{A}^{\prime}$ 「では 40〜 $50 \mathrm{ml}(\mathrm{STP}) / \mathrm{g}$ とかなりの窒 素を吸着する。一方, カルシウム型ではその細孔径が窒素吸着す るのに十分な大きさのため, 両者とも非常に多量の窒素を吸着す る。またカリウム型では八ロイサイトから生成した $\mathrm{A}^{\prime}$ も窒素を ほとんど吸着しない。これらの窒素吸着の結果から BET 法によ って表面積を求めた。その結果を表 2 に示す。 $3 \mathrm{~A} ， 4 \mathrm{~A}$ および K-A' は外部表面にしか窒素が吸着されないため, 非常に小さな 值となるが， $\mathrm{Na}-\mathrm{A}^{\prime}$ では一部の細孔内部に窒素が入るため，4 Aにくらべて表面積は大きな值となり，カルシウム型ではすべて の細孔内部に窒素が入るため, 非常に大きな表面積となってい る。

表 2 BET 法によって求めた表面積 $\left(\mathrm{m}^{2} / \mathrm{g}\right)$

$\begin{array}{lc}\text { 試 料 } & \text { 表面積 } \\ \text { M.S. 3 A } & 17 \\ \text { M.S. 4 A } & 20.4 \\ \text { M.S. 5 A } & 692 \\ \text { K-A' } & 15.4 \\ \text { Na-A' } & 187 \\ \text { Ca-A' } & 666\end{array}$

7) D. W. Breck, J. V. Smith, Sci. Am., 200, 85(1959).

8) R. M. Barrer, A. B. Robins, Trans. Faraday Soc., 49, 807(1953). 
つぎにカルシウムイオンの交換率の $\mathrm{A}$ 型ゼオライト窒素吸着に およぼす影響を調べるため, Na-A' とモレキュラーシーブ $4 \mathrm{~A}$ を濃度の異なった塩化カルシウム溶液によってイオン交換を行な って作製したカルシウムイオン交換率の異なる試料について空素 吸着を調べ，BET 法によって表面積を求めた。その窒素の吸着 量(窒素の圧力 $100 \mathrm{mmHg}$ ) 打よび表面積を表 3 に示す。モレキ ニラーシーブ $4 \mathrm{~A}$ の場合, カルシウムイオンがないとほとんど窒 素を吸着しない。ナトリウムイオンの一部がカルシウムイオンに 交換されると吸着量はわずかに増加するが，カルシウム交換率が 40\%くらいまでは余り増加の程度は大きくない。カルシウム交換 率が 45\%を越すと窒素の吸着量注急激に増加して, ほぼ 5 Aの 吸着量と同じになり，それ以上交換率が高くなっても吸着量は増 加しない。これに対して Na-A' においては前に述べたようにカ ルシウムイオンがまったくない場合でもすでに $4 \mathrm{~A}$ よりもかな 多くの窒素を吸着するととが認められ，カルシウムイオン交換率 が高くなるにつれて窒素吸着量が増加するが，その増加の割合は モレキュラーシーブ $4 \mathrm{~A}$ の場合とは異なり，カルシウム交換率が 低いところでも吸着量はかなり多くなり，最終的には $5 \mathrm{~A}$ とほぼ

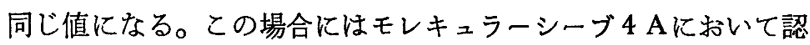
められたよらな急激な変化は認められない。

表 3 カルシウム交換率の異なるA 型ゼオライトの窒素吸着量 および表面積

\begin{tabular}{|c|c|c|c|c|c|}
\hline \multicolumn{3}{|c|}{ M.S. 4 A } & \multicolumn{3}{|c|}{$\mathrm{Na}-\mathrm{A}^{\prime}$} \\
\hline $\begin{array}{c}\mathrm{Ca} \\
\text { 交換率 }\end{array}$ & $\begin{array}{l}\text { 窒素 } \\
\text { 吸着量 }\end{array}$ & 表面積 & $\underset{\text { 交換率 }}{\mathrm{Ca}}$ & 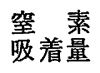 & 表面積 \\
\hline 0 & 6.6 & 20.4 & 0 & 46.5 & 187 \\
\hline 19.6 & 8.9 & 37.8 & 24.1 & 89.7 & 362 \\
\hline 35.1 & 34.1 & 142 & 37.3 & 120 & 458 \\
\hline 48.4 & 168 & 688 & 43.3 & 155 & 602 \\
\hline 56.4 & 172 & 692 & 61.0 & 169 & 677 \\
\hline 68.1 & 170 & 690 & 66.7 & 170 & 683 \\
\hline 72 & 172 & 692 & 71.8 & 170 & 685 \\
\hline
\end{tabular}

注 $\mathrm{Ca}$ 交換率: $\frac{\mathrm{CaO} \mathrm{mol}}{\mathrm{CaO}+\mathrm{Na}_{2} \mathrm{O}} \times 100, \%$.

墪素吸着量: $-196^{\circ} \mathrm{C}, \mathrm{N}_{2}$ 圧 $100 \mathrm{mmHg}, \mathrm{ml}(\mathrm{STP}) / \mathrm{g}$. 表面積: $\mathrm{m}^{2} / \mathrm{g}$.

このように窒素吸着において認められるモレキュヨーシーブA と八ロイサイトから生成した $\mathrm{A}^{\prime}$ との相違はハロイサイトを出発 物質としたA 型ゼオライトの細孔がモレキュラーシーブ Aの細孔 のように均一ではなく，モレキュラーシーブAにくらべていくぶ んか大きな細孔の結晶が存在することを示している。

\section{4 岸化水素吸着}

つぎに炭化水素類の $30^{\circ} \mathrm{G}$.における吸着等温線を求めた。 $n$-ブ タンの結果を図 4 に示す。 $4 \mathrm{~A}$ 江分子径が $4.89 \AA$ の $\mathrm{C}_{3}$ 以上の 直鎖炭化水素は吸着しないことが知られているが，本実験におい ても注とんど $n$-ブタンの吸着は認められない。これに対して $\mathrm{Na}-\mathrm{A}^{\prime}$ では窒素吸着の場合と同様に $4 \mathrm{~A}$ とは異なり，760 mmHg で $11 \%$ のーブタンを吸着することが認められた。また $5 \mathrm{~A} よ$ び $\mathrm{Ca}-\mathrm{A}^{\prime}$ では吸着量は多く, $760 \mathrm{mmHg}$ で約 19\% の吸着能を 有することが認められた。n-ヘプタンの場合にも同様の結果がえ られた。図 5 に $30^{\circ} \mathrm{G}$ における吸着等温線を示す。 $n$-ヘプタンの 場合，その吸着量は $n$-ブタンの場合とほとんど同じ值を示す。

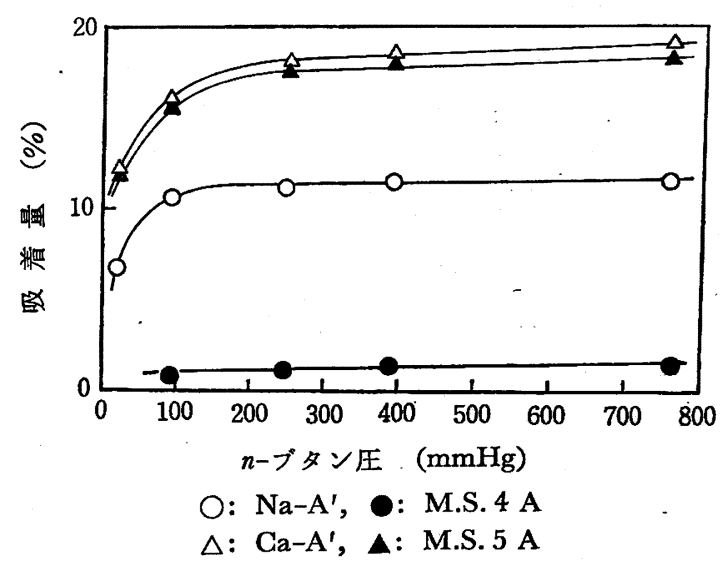

図 $4 n$-ブタン吸着等温線 $\left(30^{\circ} \mathrm{C}\right)$

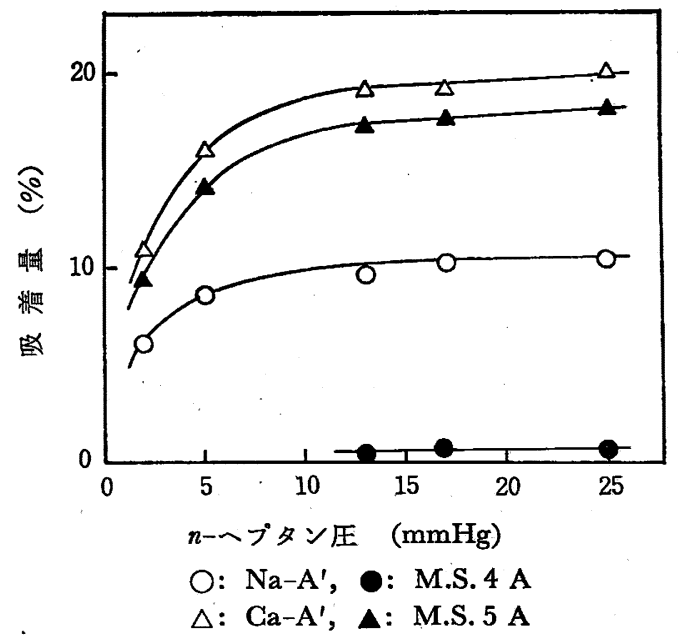

図 $5 n$-ヘプタン吸着等温線 $\left(30^{\circ} \mathrm{C}\right)$

モレキュラーシーブ A は側鎖を有する炭化水素, 芳香族炭化水 素などは吸着しない。図 6 にイソブタンの吸着等温線を示す。ナ トリウム型では $4 \mathrm{~A}$ ， Na-A' のいずれもイソブタンをまったく 吸着しない。カルシウム型では $5 \mathrm{~A}$ はほとんど吸着しないのに対 して， $\mathrm{Ca}-\mathrm{A}^{\prime}$ ではイソブタンの吸着が認められた。このことはカ ルシウム型においても，八ロイサイトから生成した $\mathbf{C a}-\mathbf{A}^{\prime}$ はモ レキュラーシーブ 5A よりも大きな細孔を有していることを示し ている。

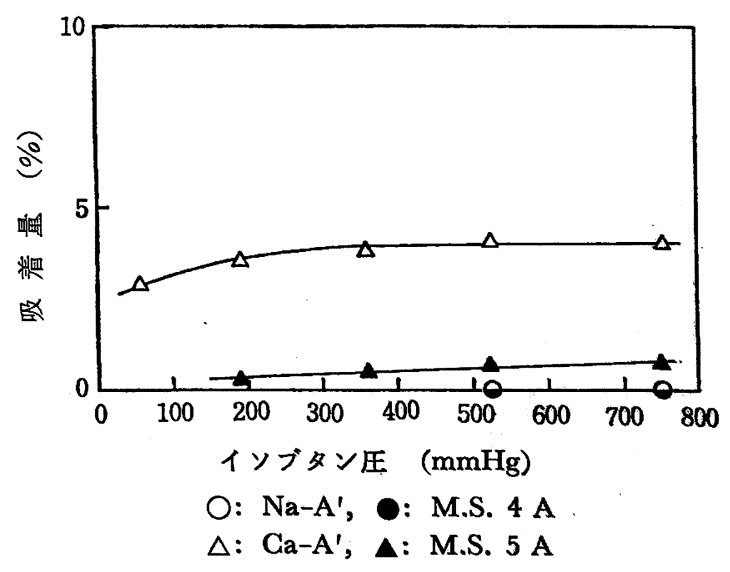

困 6 インブタン吸着等温線 $\left(30^{\circ} \mathrm{C}\right)$ 
これらの炭化水素類に刘する吸着の結果も，またハロイサイト から生成した A 型ゼオライトの平均細孔が対応するモレキュラー シーブのA 細孔より大きいことを示している。すなわち，ナトリ ウム型でも $\mathrm{C}_{3}$ 以上の直鎖炭化水素を吸着することから，その細 孔の一部は $4.9 \AA$ 以上であることを示している。

\section{4 総括}

以上の吸着実験の結果，ハロイサイトを出発物質として合成し たA 型ゼオライトの平均細孔が対応するモレキュラーシーブ Aの 細孔よりわずかに大きいことが明らかになった。ハロイサイトを 出発物質として合成した $\mathbf{A}$ 型ゼオライトは化学分析の結果から明 らかなように鉄およびマグネシウムを含んでいる。これらは塩化 カルシウム，塩化カリウム溶液などによって，イオン交換を行な っても除くことはできない。さらにゼオラィトの場合，交換順价 のもっとも高い銀による交換を行なっても鉄の含有量はほとんど
変化しない。八ロイサイトから合成したA型ゼオライトとモレキ ェラーシーブ A との吸着特性の相漌は八ロイサイト中に存在して いる鉄の影響によって生じたものと考えられる。原料中に存在し ていた鉄イオンはゼオライトが生成するさいにつきの三つの形式 で，与なわち，1）不純物として，2）交換性陽イオンとして，3) ゼオラィト骨格中に存在することが考えられる。アルカリ処理あ るいは陽イオン交換処理などを行なっても，これらの鉄は除かれ ず，ほほ一定の值を示すこと，また電子顕微鏡マイクロアナライ ザーによれば，個々の単絬品中に鉄はほほ均一に分散されている こと,さらにハロイサイトから合成した $\mathrm{A}$ 型ゼオライトがモレキ ュラーシーブAにくらべてかなり梅造がひずルでいることなどの 絬果から，鉄は不純物ああいは交换性陽イオンではなく，ゼオラ イト骨格中沉入っているものと考芯られ，対応占るモレキュラー シーブ Aとの财若特性の相遇はゼオライト骨格を形成している铁 原子の効果によるものよ将えられる。

\title{
ビシクロ[1.1.1]ペンタンの電子状態と反応性
}

(昭和 43 年 9 月 4 日受 理)

\author{
米沢貞次郎 ${ }^{* 1} \cdot$ 清水 瀞*2 森本 晴夫*2 $\cdot$ 加藤 博史*1
}

ビシクロ[1.1.1]ペンタン[1], ビシクロ[2.1.1]へキサン[2], ビシクロ[2.2.1]へプタン[3],ビシクロ[2.2.2]オクタン[4], および相当する 1-クロルビシクロ化合物類とその 1-カチオン類の電子状態を，拡張 Hückel 法および化合物〔1つについては ASMO SCF 法でも計算した。

拡張 Hückel 法によるピシクロ[1.1.1]ペンタン〔1]の構造は，数種の異なった立体配置について計算した結果，全電子エネル ギーは，図 1 における $\theta \cong 70^{\circ}\left(\gamma \cong 90^{\circ} 20^{\prime}\right)$ のとき安定となることがわかった。

また ASMO SCF 法の計算結果から，化合物〔 1 〕は $\theta$ の变化によって，その安定性および軌道の性質が大きく変化することが 明らかにされた。さらにビシクロ[1.1.1]ヘンンタン〔 1]の励起エネルギーは, $4.90 \mathrm{eV}, f=0,6.64 \mathrm{eV}, f=0.147$ とえられたが， この励起エネルギーの值はオレフィンの励起エネルギーに近い值である。

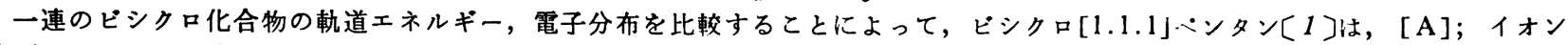
化ボテンシャルが小さく, 電子親和力に富んでおり，[B]; 橋頭炭素-水素間結合では $s$ 性が大きく, 㢶三級水素間の結合定数が 大きいこと, [C] ] ビシクロ[1.1.1]ペンタン環は電子吸引力が大きいということが明らかにされている。

最後に, 1-クロルビシクロ化合物の加溶媒分解反応について,そのカチオンの電子分布からビシクロ[1.1.1]ヘンタン䍗およびビ シクロ[2.1.1]へキサン環は開環生成物を生じるが,ビシクロ[2.2.1]へブタン環およびビシクロ[2.2.2]オクタン環は環開裂の起こ らないことを明らかにしえた。

\section{1 緒 言}

ビシクロ[1.1.1]ペンタン〔1]は, 1964 年 Wiberg ら1) によ り合成された新しい化合物であって，結合角のひずみが大きく， 2 個の橋頭炭素原子間距離が非常に短い構造をもつと予想される 化合物である。そしてこの特異な構造に起因すると考えられる物 理化学的性質が明らかにされるようになった。たとえば NMR 吸収スペクトルの測定によると,ビシクロ[1.1.1]ペンタン環の橋 頭炭素につく第三級水素問の $\mathrm{H}-\mathrm{H}$ 絬合定数が $18 \mathrm{cps}$ と, ビシ

*1 Teijiro Yonezawa, Hiroshi Kato 京都大学工学部, 京都市左京区吉田本町

*2 Kiyoshi Shimizu, Haruo Morimoto 日東紡績株式会 社化織研究所, 福島県郡山市富久山町

1) K. B. Wiberg, D. S. Connor, G. M. Lampman, Tetrahedron Letters, 1964, 531.
ク口化合物のなかで最大の值を示すこと2), 橋頭炭素-第三級水素 間の $\mathrm{C}^{13}-\mathrm{H}$ 結合定数が $164 \mathrm{cps}^{2)}$ とかなり大きいこと，橋頭置換 ハロゲン化物の加溶媒分解反応ではビシクロ[1.1.1]ペンタン環 骨格が保持されず開裂した生成物を生じるが，その反応速度はか なりはやいことなどが示されている3。

一方,ビシクロ[1.1.1]ペンタン〔 1]を理論的に考察した例とし ては, Maksić 54)が, Maximum Overlap 法5)を用いて[1]の混

2) K. B. Wiberg, G. M. Lampman, R. P. Ciula, D. S. Connor, P. Schertler, J. Lavanish, Tetrahedron, 21, 2749(1965).

3) K. B. Wiberg, V. Z. Williams, Jr., J. Am. Chem. Soc., 89, 3373(1967).

4) Z. Maksić, L. Klasinc, M. Randić, Theoret. Chim. Acta (Berl), 4, 273(1966).

5) たとえば, L. Pauling, “The Nature of the Chemical Bond ", 3 rd. Edn., Cornell Univ. Press. Ithaca (1960) p. 108 , 